\title{
Comparative Analysis on Antioxidant and Antibacterial Activity of Pumpkin Wastes
}

Ismail Ismail Abdullahi* and Infant Santhose

Department of Biotechnology, Faculty of Science and Humanities, SRM University Chennai, India

"Corresponding author: Abdullahi II, Department of Biotechnology, Faculty of Science and Humanities, SRM University Chennai, India, E-mail: ismailbangis.iia@gmail.com

Received date: August 24, 2018; Accepted date: September 05, 2018; Published date: September 11, 2018

Copyright: @2018 Abdullahi II, et al. This is an open-access article distributed under the terms of the Creative Commons Attribution License, which permits unrestricted use, distribution, and reproduction in any medium, provided the original author and source are credited.

\begin{abstract}
Pumpkin is a member of Cucurbitaceae family grown for nutritional and medicinal use throughout the world. The pumpkin flesh is the main part used for consumption while other parts are mostly discarded as waste. These wastes include the seeds, back and the brain (the fibrous inner part).

In current study, Antioxidant analysis of methanol extract of the seed, back and brain shows that the samples are potential antioxidants against free radicals. The best DPPH antioxidant scavenging was given by the back sample $(74.05 \% \pm 7.1 \%)$ at a concentration of $120 \mu \mathrm{g} / \mathrm{ml}$ of the sample although no significant difference was reported with brain sample at $p<0.05$ degree of freedom. All the three show similar $\mathrm{OH}$ radical scavenging power (within $98 \%$ ). Brain and back samples have more Iron and phosphomolybdenum reducing power than seed. The antibacterial effect was reported by back sample against Klebsiella $(0.77 \mathrm{~cm}$ zone of inhibition) and brain against Bacillus subtilis $(0.75 \pm 0.06 \mathrm{~cm}$ zone of inhibition).
\end{abstract}

Keywords: Pumpkin; Seed; Brain; Antioxidant; Antibacterial

\section{Introduction}

Pumpkin is botanically defined as fruit although commonly it is regarded as vegetable in consumer terms [1]. The family of Cucurbitaceae is a wide group of plant species of approximately 130 genera and 800 species [2]. They are characterized by fleshy large fruit attached to climbing herbaceous vines [3]. The plant is more suited for cultivation in regions with warmer climate worldwide and makes a widespread food plants which include squashes, pumpkins, melons and gourds [3,4]. By having the ability to grow in the subtropical and temperate regions of the world, the pumpkin is considered as an economically important member of the Cucurbitaceae family and was reported is among the top ten vegetables worldwide [5].

The plant has been reported to play vital important roles in nutritional, medicinal and even social and historical advances for decades of years. Despite reported importance, its existence is currently being at stake due to negligence and disregards. In countries like Nigeria and Kenya, the plant is cultivated at subsistence level with virtually no commercial importance $[3,6]$. For domestic use, only the flesh or pulp is considered useful while the other parts are discarded as waste. The fruit wastes include the back peel, seeds and pumpkin brain.

These parts may provide nutritional and pharmacological effects similar or even more to those provided by the pumpkin pulps. Among the waste parts, only the seeds and to some extend the back gained scientific attention. Within the limit of the researcher's survey, very few studies have been reported about the brains. Current study is working towards regaining the fruit's integrity through exploration of the antioxidant and antibacterial properties of the pumpkin wastes. This may provide a focal point for pharmaceutical industries to use the fruit and its wastes as raw material.

\section{Materials and Methods}

\section{Plant material}

Fresh pumpkin of commercial maturity was obtained from a local market in Potheri, Kattankulathur, Chennai, India. It is a Cucurbita pepo species of Indian origin. The sample was selected by random sampling from the shelf.

Preparation of samples: The fruits were carefully washed with running tap water followed by drying with a soft cloth.

Sample separation: Using a clean knife, the back was carefully peeled and kept in a clean beaker. To obtain the brain and seed samples, the fruit was cut to expose the inner part. The fibrous part "Brain" (to which the seeds are attached to) were separated carefully from the flesh. The seeds and the brain separated and kept in separate beakers.

For the brain and the back: Fresh brain and back samples were collected in separate containers. Each was then added with equal volume of distilled water at a ratio of 1:1(v:v) and homogenized using electric blender. The homogenate was then filtered using muslin cloth. The supernatant was oven dried at $500^{\circ} \mathrm{C}$. The powdered sample was then collected in an air tight container and stored at low temperature for the next step.

For the seeds: The seeds were first dried under shade. The dried seeds were then crushed into powder using clean mortar and pestle. At this stage, same homogenization procedure for the back and brains was then followed.

\section{Sample extraction}

All the three samples were extracted using extraction method adopted from Velioglu et al. (with some modifications) [7]. 2 grams of 
each of the three samples were extracted using $2 \mathrm{ml}$ of a solution containing methanol, hydrochloric acid and distilled water in the ratio 80:1:19 in a $15 \mathrm{ml}$ vial. The vial was kept on an orbital shaker set at 200 rpm for 2 hours at room temperature. The mixture was then centrifuged at $1000 \mathrm{~g}$ for 15 minutes and the supernatant was collected in another $15 \mathrm{ml}$ vial. The procedure was repeated two more times for the sample to get maximum extraction.

The resulting extract was then used for antioxidant assays: (ferric reducing antioxidant power, 1,1-diphenyl-2-picrylhydrazyl (DPPH) analyses, $\mathrm{OH}$ radical scavenging assay and phosphomolybdenum reduction assay) and antimicrobial activity against human pathogens (Klebsiellae, Bacillus cerus, Staphylococcus aurius, Proteus, Bacillus subtilis, Pseudomonas and Serratia marcescens).

\section{Antioxidant assay}

Iron $\left(\mathrm{Fe}^{3+}\right)$ reducing power assay: The Iron reducing power assay was conducted using protocol adopted from Yen and Chen [8]. To the various concentrations of the sample $(10-60 \mu \mathrm{g} / \mathrm{ml})$ in a test tube, $1 \mathrm{ml}$ of phosphate buffer $(0.2 \mathrm{M}, \mathrm{pH}-6.6)$ was added. Then $1 \mathrm{ml}$ of potassium ferricyanide was added and allowed to incubate at $500^{\circ} \mathrm{C}$ for 20 minutes. After cooling to room temperature, $500 \mu \mathrm{l}$ of $10 \%$ TCA (trichloro acetic acid) was added followed by $500 \mu$ of freshly prepared $0.01 \%$ (0.01 grams of iron (III) chloride $\mathrm{FeCl}_{3}$ in $100 \mathrm{ml}$ of distilled water). The absorbance was read at $700 \mathrm{~nm}$ wavelength.

Phosphomolybdenum reducing assay: The phosphomolybdenum reduction assay was determined by Prieto et al. [9]. $1 \mathrm{ml}$ of different concentrations of the sample $(20-120 \mu \mathrm{g} / \mathrm{ml})$ was taken in a test tube and $1 \mathrm{ml}$ of the reagent $(0.6 \mathrm{M}$ sulphuric acid, $28 \mathrm{mM}$ sodium phosphate and $4 \mathrm{mM}$ ammonium molybdate) was added. The tubes were capped and then incubated in water bath at $95^{\circ} \mathrm{C}$ for 90 minutes. Ascorbic acid was used as standard. The absorbance was read at 695 $\mathrm{nm}$ against a blank after cooling to room temperature.

Hydroxyl radical scavenging assay: Hydroxyl radical scavenging test was done according to the method described by Klenin et al. [10]. $1 \mathrm{ml}$ of various concentrations $(20-120 \mu \mathrm{g} / \mathrm{ml})$ of the sample was taken in test tubes followed by $1 \mathrm{ml}$ of solution of iron-EDTA $(0.26 \%$ EDTA and $0.13 \%$ ferrous ammonium sulphate), $0.5 \mathrm{ml}$ of EDTA solution $(0.018 \%)$ and $1 \mathrm{ml}$ of DMSO $(0.85 \% \mathrm{v} / \mathrm{v}$ in $0.1 \mathrm{M}$ phosphate buffer, $\mathrm{pH} 7.4)$. The reaction was allowed to initiate by adding $0.5 \mathrm{ml}$ of $0.22 \%$ ascorbic acid. The tubes were then incubated for 15 minutes at $900^{\circ} \mathrm{C}$ in a water bath.

After the incubation, the reaction was stopped by addition of $0.5 \mathrm{ml}$ of $17.5 \% \mathrm{w} / \mathrm{v}$ ice cold TCA solution. $3 \mathrm{ml}$ of Nash reagent ( 7.5 grams of ammonium acetate, $0.5 \mathrm{ml}$ of glacial acetic acid and $0.2 \mathrm{ml}$ of acetyl acetone were mixed and made up to $100 \mathrm{ml}$ with distilled water) was then added and left at room temperature for 15 minutes.

The reaction mixture without sample was used as control. The colour intensity formed was measured spectrophotometrically at 412 $\mathrm{nm}$ against reagent blank. Using the formula below, the percentage of hydroxyl radical scavenging activity was calculated.

$$
\% \text { of } \mathrm{OH} \text { inhibition }=\frac{\text { control }- \text { sample }}{\text { control }} \times 100
$$

DPPH radical scavenging assay: The DPPH free radical scavenging activity was carried out according to the method of Blois [11]. $1 \mathrm{ml}$ of plant extract of various concentrations $(5-30 \mu \mathrm{g} / \mathrm{ml})$ was mixed with 1 $\mathrm{ml}$ of $0.1 \mathrm{mM}$ DPPH solution in methanol. The reaction mixture was kept in dark at room temperature for 30 minutes. Absorbance was read at $517 \mathrm{~nm}$ in spectrophotometer. The percentage of the radical scavenging activity was calculated as follows.

$$
\% \text { of inhibition }=\frac{\text { control }- \text { sample }}{\text { control }} \times 100
$$

\section{Antimicrobial assay}

The microbial species Klebsiellae, Bacillus cerus, Staphylococcus aurius, Proteus, Bacillus subtilis, Pseudomonas and Serratia marcescens were used for antimicrobial assay of the samples.

Preparation of microbial culture: About 0.065 grams nutrient broth was dissolved in $5 \mathrm{ml}$ distilled water contained in a test tube. The test tube was covered with cotton and autoclaved at $121^{\circ} \mathrm{C}$ for 15 minutes. The media was allowed to cool and 0.01 grams of the bacterium was inoculated in the test tube in an aseptic condition. The culture is then incubated at $37^{\circ} \mathrm{C}$ for 24 hours.

Preparation of culture plate: The method was adopted from Jagessar et al. [12]. Muller Hilton (MH) media purchased from HiMedia (HIMEDIA-M173-500G) was used for the culture plates' preparation to make up the bacterial medium, 39 grams of $\mathrm{MH}$ media was dissolved in $1000 \mathrm{ml}$ of distilled water in a $5 \mathrm{~L}$ flask. It was then stirred and boiled to dissolve followed by autoclaving at $15 \mathrm{lbs}$ pressure and temperature of $121^{\circ} \mathrm{C}$ for 15 minutes. The $\mathrm{pH}$ of the media was between 7.0-7.5. It was then allowed to cool to hand bearable temperature and poured in sterilized petri plates in an aseptic condition.

After solidification, the bacterial culture was swabbed on the culture plates using sterile cotton swab in lamina air flow. Using a sterilized puncture, five equidistant holes were made in the plate (four by the sides and one at the centre). The wells were labeled positive control, negative control, $25 \mu \mathrm{l}, 50 \mu \mathrm{l}$ and $75 \mu \mathrm{l}$.

Different volumes $(25 \mu \mathrm{l}, 50 \mu \mathrm{l}$ and $75 \mu \mathrm{l})$ of the sample $(0.1 \mathrm{mg} / \mathrm{ml})$ were added into the labeled wells. $10 \mu \mathrm{l}$ of methanol was added into the well labeled negative control and $10 \mu \mathrm{l}$ ampicillin was added to the well labeled positive control. The plates were then incubated at $37^{\circ} \mathrm{C}$ for 24 hours and the zones of inhibition were measured. Growth inhibition was compared with the reference drug.

\section{Statistical analysis}

All data were given as average mean \pm standard deviation of triplicates values. Analysis of variance was done by ANOVA test using Microsoft excel 2010 software. Charts and graphs were developed using Microsoft excel 2010 and graph software downloaded from https://graph.en.softonic.com/download.

\section{Results}

\section{Antioxidant activities}

The result indicates that among the three samples, the back and brain sample has the highest iron reducing power when compared with seed samples at $\mathrm{p}<0.05$. The highest reducing power was observed at concentration of $60 \mu \mathrm{g} / \mathrm{ml}$. The seed sample show the least iron reducing power among the three samples with the least OD value of $0.11 \pm 0.03$ at $10 \mu \mathrm{g} / \mathrm{ml}$.

The phosphomolydate reducing power was shown to be dose related. As the concentration is increasing, the $\mathrm{OD}$ value is also 
Page 3 of 6

increasing. At lower concentration $(1.533 \pm 0.05 \mathrm{OD}$ at $20 \mu \mathrm{g} / \mathrm{ml})$, the back sample show higher phosphomolybenum reducing power.

However, the highest $\mathrm{OD}$ was given by brain sample at concentration of $120 \mu \mathrm{g} / \mathrm{ml}$ although it does not differ significantly with the OD of back sample at $\mathrm{p}<0.05$. The least OD was obtained from seed sample at $20 \mu \mathrm{g} / \mathrm{ml}$ (Tables 1 and 2 ).

\begin{tabular}{|c|c|c|c|}
\hline \multirow{2}{*}{$\begin{array}{c}\text { Concentration } \\
(\boldsymbol{\mu g} / \mathbf{m l})\end{array}$} & \multicolumn{3}{|c|}{ Optical density (OD) } \\
\cline { 2 - 4 } & Brain & Back & Seed \\
\hline 10 & $0.527 \pm 0.03^{\mathrm{a}}$ & $0.62 \pm 0.02^{\mathrm{b}}$ & $0.11 \pm 0.03^{\mathrm{a}, \mathrm{b}}$ \\
\hline 20 & $0.683 \pm 0.02^{\mathrm{c}}$ & $0.7 \pm 0.05^{\mathrm{d}}$ & $0.173 \pm 0.02^{\mathrm{c}, \mathrm{d}}$ \\
\hline 30 & $0.81 \pm 0.01^{\mathrm{e}}$ & $0.817 \pm 0.02^{\mathrm{f}}$ & $0.267 \pm 0.03^{\mathrm{e}, \mathrm{f}}$ \\
\hline 40 & $0.95 \pm 0.04^{\mathrm{g}}$ & $0.887 \pm 0.03^{\mathrm{h}}$ & $0.317 \pm 0.04^{\mathrm{g}, \mathrm{h}}$ \\
\hline 50 & $0.97 \pm 0.01^{\mathrm{i}}$ & $0.93 \pm 0.04^{\mathrm{j}}$ & $0.343 \pm 0.01^{\mathrm{i}, \mathrm{j}}$ \\
\hline 60 & $0.987 \pm 0.03^{\mathrm{k}}$ & $1.013 \pm 0.18^{\mathrm{l}}$ & $0.337 \pm 0.04^{\mathrm{k}, \mathrm{l}}$ \\
\hline
\end{tabular}

Values are mean \pm standard deviation, $\mathrm{n}=3$.

Values having similar superscript differ significantly at $p<0.05$ degree of freedom.

Table 1: Iron reducing power.

\begin{tabular}{|c|c|c|c|}
\hline \multirow{2}{*}{$\begin{array}{c}\text { Concentration } \\
(\mu \mathrm{g} / \mathrm{ml})\end{array}$} & \multicolumn{3}{|c|}{ Optical density (OD) } \\
\cline { 2 - 4 } & Brain & Back & Seed \\
\hline 20 & $1.303 \pm 0.05^{\mathrm{a}}$ & $1.533 \pm 0.05^{\mathrm{b}}$ & $0.011 \pm 0.00^{\mathrm{a}, \mathrm{b}}$ \\
\hline 40 & $1.403 \pm 0.05^{\mathrm{c}}$ & $1.643 \pm 0.01^{\mathrm{d}}$ & $0.02 \pm 0.00^{\mathrm{c}, \mathrm{d}}$ \\
\hline 60 & $1.557 \pm 0.08^{\mathrm{e}}$ & $1.753 \pm 0.03^{\mathrm{f}}$ & $0.028 \pm 0.02^{\mathrm{e}, \mathrm{f}}$ \\
\hline 80 & $1.607 \pm 0.07^{\mathrm{g}}$ & $1.863 \pm 0.01^{\mathrm{h}}$ & $0.197 \pm 0.05^{\mathrm{g}, \mathrm{h}}$ \\
\hline 100 & $1.85 \pm 0.04^{\mathrm{i}}$ & $1.877 \pm 0.02^{\mathrm{j}}$ & $0.28 \pm 70.0^{\mathrm{i}, \mathrm{j}}$ \\
\hline 120 & $1.887 \pm 0.03^{\mathrm{k}}$ & $1.863 \pm 0.06^{\mathrm{l}}$ & $0.373 \pm 0.02^{\mathrm{k}, \mathrm{l}}$ \\
\hline $\begin{array}{l}\text { Values are mean } \pm \text { standard deviation, n=3. } \\
\text { Values having similar superscript differ significantly at } \mathrm{p}<0.05 \text { degree of } \\
\text { freedom. }\end{array}$
\end{tabular}

Table 2: Phosphomolybdenum reducing assay.

The percentage $\mathrm{OH}$ radical scavenging activity of the samples shows that, as the concentration of the sample is increasing, the scavenging ability of the sample is also increasing. The least percentage $\mathrm{OH}$ scavenging power was observed in brain sample at concentration of 20 $\mu \mathrm{g} / \mathrm{ml}$. all the three samples gave highest similar scavenging ability at $120 \mu \mathrm{g} / \mathrm{ml}$ of the samples (Table 3).

The DPPH radical scavenging assay show that, the back sample has the highest scavenging capacity $(74.05 \% \pm 7.1 \%$ at $120 \mu \mathrm{g} / \mathrm{ml}$ concentration) compared to the other two samples. The least percentage DPPH scavenging was given by brain sample at $20 \mu \mathrm{g} / \mathrm{ml}$ concentration.

Although, at lower concentration of the sample $(20 \mu \mathrm{g} / \mathrm{ml})$ the seed sample has more \%DPPH scavenging capacity than brain sample, reverse is the case at $120 \mu \mathrm{g} / \mathrm{ml}$ concentration of the sample (Table 4).

\begin{tabular}{|c|c|c|c|}
\hline \multirow{2}{*}{$\begin{array}{c}\text { Concentration } \\
(\mu \mathrm{g} / \mathrm{ml})\end{array}$} & Brain & Back & Seed \\
\cline { 2 - 4 } & $28.168 \pm 0.03^{\mathrm{a}}$ & $33.818 \pm 0.01^{\mathrm{b}}$ & $53.995 \pm 0.01^{\mathrm{a}, \mathrm{b}}$ \\
\hline 20 & $71.357 \pm 0.03^{\mathrm{c}}$ & $73.018 \pm 0.01^{\mathrm{d}}$ & $35.658 \pm 0.68^{\mathrm{c}, \mathrm{d}}$ \\
\hline 40 & $85.164 \pm 0.01$ & $89.088 \pm 0.01$ & $87.318 \pm 0.01$ \\
\hline 60 & $92.341 \pm 0.01$ & $93.037 \pm 0.01$ & $94.778 \pm 0.04$ \\
\hline 80 & $85.386 \pm 0.47$ & $96.798 \pm 0.00$ & $96.546 \pm 0.01$ \\
\hline 100 & $98.405 \pm 0.01$ & $98.61 \pm 0.00$ & $98.063 \pm 0.01$ \\
\hline 120 & \multicolumn{3}{|c|}{} \\
\hline $\begin{array}{l}\text { Values are mean } \pm \text { standard deviation, } \mathrm{n}=3 . \\
\text { Values having similar superscript differ significantly at } \\
\text { freedom. }\end{array}$ & \multicolumn{3}{l}{} \\
\hline
\end{tabular}

Table 3: $\mathrm{OH}$ radical scavenging.

\begin{tabular}{|c|c|c|c|}
\hline \multirow{2}{*}{$\begin{array}{c}\text { Concentration } \\
(\mu \mathrm{g} / \mathrm{ml})\end{array}$} & \multicolumn{3}{|c|}{$\%$ Inhibition } \\
\cline { 2 - 4 } & Brain & Back & Seed \\
\hline 20 & $6.69 \pm 0.51^{\mathrm{a}, \mathrm{b}}$ & $16.30 \pm 3.1^{\mathrm{a}}$ & $16.10 \pm 2.2^{\mathrm{b}}$ \\
\hline 40 & $19.00 \pm 1.2^{\mathrm{c}, \mathrm{d}}$ & $30.10 \pm 1.5^{\mathrm{c}}$ & $32.20 \pm 4.1^{\mathrm{d}}$ \\
\hline 60 & $34.5 \pm 1.7$ & $35.90 \pm 4.2$ & $38.70 \pm 1.9$ \\
\hline 80 & $46.02 \pm 2.9$ & $47.60 \pm 14.3$ & $50.53 \pm 2.6$ \\
\hline 100 & $57.00 \pm 1.6$ & $67.70 \pm 3.3^{\mathrm{d}}$ & $51.60 \pm 3.8^{\mathrm{d}}$ \\
\hline 120 & $66.00 \pm 3.3$ & $74.05 \pm 7.1$ & $56.90 \pm 2.9$ \\
\hline
\end{tabular}

Values are mean \pm standard deviation, $n=3$

Values having similar superscript differ significantly at $p<0.05$ degree of freedom.

Table 4: DPPH radical scavenging.

\section{Antibacterial assay}

The result of antibacterial assay of the samples against seven human pathogens indicates that, the back sample has the most effect against the tested bacteria followed by brain and the seed respectively.

The least antibacterial activity was observed against Proteus bacteria at sample volume of $25 \mu \mathrm{l}(0.00 \mathrm{~cm}$ zone of inhibition $)$, while the highest antibacterial activity was observed against Klebsiella $(0.77 \mathrm{~cm}$ zone of inhibition) by back sample at volume of $75 \mu$ l. Majority of the bacteria tested show less sensitivity to the samples used (Table 5). The highest antibacterial activity was given by the back sample followed by brain and seed respectively.

Most of the growth inhibitory effects were dose dependent. No activity was recorded against Proteus bacterial species by all the three samples at $25 \mu \mathrm{l}$ sample assay although; the positive control had antibacterial activity against the organism.

The highest antibacterial capacity was given by back sample $(0.77$ $\mathrm{cm})$ at $75 \mu \mathrm{l}$ against Klebsiella spp. The activity reported significant difference with that reported for the positive control (penicillin). 
Citation: Abdullahi II and Santhose I (2018) Comparative Analysis on Antioxidant and Antibacterial Activity of Pumpkin Wastes. J Antimicrob Agents 4: 180. doi:10.4172/2472-1212.1000180

Page 4 of 6

\begin{tabular}{|c|c|c|c|c|c|}
\hline \multirow{2}{*}{ S. No. } & \multirow{2}{*}{ Bacterial species } & \multirow{2}{*}{ Volume of $0.1 \mathrm{~g} / \mathrm{ml}$ extract $(\mu \mathrm{l})$} & \multicolumn{3}{|c|}{ Zone of inhibition $(\mathrm{cm})$} \\
\hline & & & Back & Brain & Seed \\
\hline \multirow{4}{*}{1} & \multirow{4}{*}{ Bacillus cereus } & +ve control & $0.53 \pm 0.06$ & $0.53 \pm 0.06$ & $0.50 \pm 0.00$ \\
\hline & & 25 & $0.17 \pm 0.06$ & $0.17 \pm 0.06$ & $0.27 \pm 0.15$ \\
\hline & & 50 & $0.37 \pm 0.06$ & $0.37 \pm 0.06$ & $0.47 \pm 0.21$ \\
\hline & & 75 & $0.47 \pm 0.06$ & $0.47 \pm 0.06$ & $0.57 \pm 0.21$ \\
\hline \multirow{4}{*}{2} & \multirow{4}{*}{ Bacillus subtilis } & +ve control & $0.47 \pm 0.06$ & $0.77 \pm 0.06$ & $0.71 \pm 001$ \\
\hline & & 25 & $0.00 \pm 0.00$ & $0.23 \pm 0.06$ & $0.10 \pm 0.01$ \\
\hline & & 50 & $0.10 \pm 0.00$ & $0.40 \pm 0.00$ & $0.21 \pm 0.01$ \\
\hline & & 75 & $0.33 \pm 0.06^{\mathrm{a}}$ & $0.75 \pm 0.06^{a, b}$ & $0.23 \pm 0.06^{b}$ \\
\hline \multirow{4}{*}{3} & \multirow{4}{*}{ Klebsiellae } & +ve control & $0.67 \pm 0.06$ & $0.73 \pm 0.06$ & $0.73 \pm 0.06$ \\
\hline & & 25 & $0.23 \pm 0.06$ & $0.37 \pm 0.06$ & $0.10 \pm 0.00$ \\
\hline & & 50 & $0.47 \pm 0.06$ & $0.37 \pm 0.06$ & $0.33 \pm 0.06$ \\
\hline & & 75 & $0.77 \pm 0.06^{c}$ & $0.67 \pm 0.06$ & $0.57 \pm 0.06^{c}$ \\
\hline \multirow{4}{*}{4} & \multirow{4}{*}{ Staphylococcus Aureus } & +ve control & $0.80 \pm 0.10$ & $0.80 \pm 0.1$ & $0.80 \pm 0.00$ \\
\hline & & 25 & $0.17 \pm 0.06$ & $0,17 \pm 0.06$ & $0.07 \pm 0.06$ \\
\hline & & 50 & $0.37 \pm 0.06$ & $0.30 \pm 0.00$ & $0.31 \pm 0.10$ \\
\hline & & 75 & $0.57 \pm 0.06$ & $0.53 \pm 0.06$ & $0.33 \pm 0.06$ \\
\hline \multirow{4}{*}{5} & \multirow{4}{*}{ Proteus } & +ve control & $0.77 \pm 0.15$ & $0.23 \pm 0.06$ & $0.53 \pm 0.06$ \\
\hline & & 25 & $0.27 \pm 0.06$ & $0.00 \pm 0.00$ & $0.00 \pm 0.00$ \\
\hline & & 50 & $0.47 \pm 0.06$ & $0.07 \pm 0.06$ & $0.13 \pm 0.06$ \\
\hline & & 75 & $0.43 \pm 0.06$ & $0.23 \pm 0.06$ & $0.27 \pm 0.06$ \\
\hline \multirow{4}{*}{6} & \multirow{4}{*}{ Pseudomonas } & +ve control & $0.23 \pm 0.06$ & $0.33 \pm 0.12$ & $0.37 \pm 0.06$ \\
\hline & & 25 & $0.13 \pm 0.06$ & $0.10 \pm 0.00$ & $0.07 \pm 0.06$ \\
\hline & & 50 & $0.27 \pm 0.06$ & $0.13 \pm 0.06$ & $0.23 \pm 0.12$ \\
\hline & & 75 & $0.40 \pm 0.10$ & $0.18 \pm 0.08$ & $0.30 \pm 0.10$ \\
\hline \multirow{4}{*}{7} & \multirow{4}{*}{ Serratia marcescens } & +ve control & $0.40 \pm 0.10$ & $0.33 \pm 0.06$ & $0.33 \pm 0.06$ \\
\hline & & 25 & $0.17 \pm 0.06$ & $0.00 \pm 0.00$ & $0.03 \pm 0.06$ \\
\hline & & 50 & $0.27 \pm 0.06$ & $0.00 \pm 0.00$ & $0.27 \pm 0.06$ \\
\hline & & 75 & $0.37 \pm 0.06$ & $0.07 \pm 0.06$ & $0.43 \pm 0.06$ \\
\hline
\end{tabular}

Table 5: The antibacterial properties of back, brain and seed samples of pumpkin.

\section{Discussion}

For many decades, foods that are based on plants are known to provide significant health benefits [1]. They contain bioactive compounds (also called phytochemicals) of different varieties that have been proven to possess activity against degenerative disorders such as cancer and cardiovascular disease in addition to their nutritional property [13].

All the three samples assessed show antioxidant properties. In both iron reducing and phosphomolybdenum assays, no significant difference was observed between the back and brain samples. Both show high reducing ability on the reagent used. In contrast to seed 
sample, a lower reducing power was recorded $(0.11 \pm 0.03$ at $10 \mu \mathrm{g} / \mathrm{ml}$ and $0.337 \pm 0.04$ at $60 \mu \mathrm{g} / \mathrm{ml})$ in comparison with brain $(0.527 \pm 0.03$ at $10 \mu \mathrm{g} / \mathrm{ml}$ and $0.987 \pm 0.03$ at $60 \mu \mathrm{g} / \mathrm{ml})$ and back $(0.62 \pm 0.02$ at 10 $\mu \mathrm{g} / \mathrm{ml}$ and $1.013 \pm 0.18$ at $60 \mu \mathrm{g} / \mathrm{ml}$ ). For back and brain samples, there was exponential increase in iron and phosphomolybdenum reduction at lower concentrations of the samples $(10,20$ and $30 \mu \mathrm{g} / \mathrm{ml})$. However, a decline was observed as the concentration of the sample increases above $30 \mu \mathrm{g} / \mathrm{ml}$, similar pattern was observed in case of iron reduction by seed sample but a complete opposite in phosphomolybdenum reduction. For $\mathrm{OH}$ and $\mathrm{DPPH}$ radical scavenging, all the three samples show an antioxidant activity in a dose-dependent manner. The least \%radical scavenging was observed in brain sample $(28.168 \pm 0.03)$ at $20 \mu \mathrm{g} / \mathrm{ml}$ concentration while the highest was observed in back sample $(98.61 \pm 0.00)$ though without any significant difference with other (brain and seeds) samples. Also the back had shown the highest ( $74.05 \%$ at $120 \mu \mathrm{g} / \mathrm{ml}$ ) DPPH radical scavenging compared to the seed and brain samples and the least was the seed samples. The result of current study is in conformity with that presented earlier regarding the back sample [5]. An ethanolic extract pumpkin shell (considered back here) gave a highest DPPH radical scavenging property $(71.0 \pm 0.97)$. According to previous study, the back sample has higher DPPH radical scavenging power $(1.47 \%-70.96 \%)$ compared to the pumpkin seed (1.47\%-49.74\%) [5]. A relatively higher DPPH radical scavenging was reported for fresh pumpkin flesh $(78.4 \pm 1.7)$ [1]. Previous studies reported $50.03 \% \pm 5.03 \% \mathrm{DPPH}$ radical scavenging capacity of raw Pumpkin (Cucurbita moschata) seeds cultivated in Lemnos [14,15]. This result is in conformity with DPPH radical scavenging activity of seed $(51.60$ at $100 \mu \mathrm{g} / \mathrm{ml})$ reported in this study. In addition, result from current study also show relatively similar \%DPPH radical scavenging activity of methanol extract of pumpkin seeds reported by [16]. Results of $\mathrm{Fe}^{3+}$ reducing power obtained from also show that the methanol extract of pumpkin seed is higher than that reported in this study but similar to iron reduction of pumpkin brain and lower than that of pumpkin back in this study [16]. A 2010 study on the antioxidant properties of cluster figures revealed similar \%DPPH radical scavenging activity (20.36\% to $54.81 \%$ inhibition) to seed from present study and lower than the back and brain samples of the values found for the pumpkin shell samples in the present study [17].

The highest antibacterial activity was given by the back sample followed by brain and seed respectively. Most of the growth inhibitory effects were dose dependent. No activity was recorded against Proteus bacterial species by all the three samples at $25 \mu \mathrm{l}$ sample assay although; the positive control had antibacterial activity against the organism. The highest antibacterial capacity was given by back sample $(0.77 \mathrm{~cm})$ at $75 \mu \mathrm{l}$ against Klebsiella spp. The activity reported significant difference with that reported for the positive control (penicillin). According to dissertation presented by Singh, disc method of antimicrobial activity of Cucurbita maxima seed gave a zone of inhibition of $2.8 \mathrm{~cm}, 16 \mathrm{~cm}$ and $10 \mathrm{~cm}$ for Staphylococcus aureus, Bacillus subtilis and Klebsiella pneumoniae respectively. This result show higher antimicrobial activity of the plant than those reported in this study. Also, reported higher antimicrobial zone of inhibition against Staphylococcus aureus, Bacillus subtilis and Pseudomonas aeruginosa by pumpkin methanolic $(18 \mathrm{~mm}, 22 \mathrm{~mm}$ and $18 \mathrm{~mm}$ for Bacillus subtilis and Pseudomonas aeruginosa respectively and aqueous extracts $(10 \mathrm{~mm}, 12 \mathrm{~mm}$ and $16 \mathrm{~mm}$ for Bacillus subtilis and Pseudomonas aeruginosa respectively) at $20 \mathrm{mg} / \mathrm{ml}$ concentration of the extract using well diffusion method [18]. However, the volume of the extract administered to the wells was not stated. Also it has been reported that higher antimicrobial activity of methanolic extract of pumpkin seed (lowest $7 \mathrm{~mm}$ at $500 \mu \mathrm{g} /$ disc and highest $9 \mu \mathrm{g} / \mathrm{disc}$ at $2000 \mu \mathrm{g} / \mathrm{disc}$ ) and back peel (lowest $7 \mathrm{~mm}$ at $500 \mu \mathrm{g} / \mathrm{disc}$ and highest $10 \mu \mathrm{g} / \mathrm{disc}$ at $2000 \mu \mathrm{g} / \mathrm{disc}$ ) against Staphylococcus aureus compared to current study [19]. They used disc diffusion method at a concentration of 500, 1000 and $2000 \mu \mathrm{g} /$ disc. As reported, methanolic extract of both Iraqi and Chinese pumpkin seeds had shown higher antimicrobial activity against $S$. aurens $(16 \mathrm{~mm}$ and $10 \mathrm{~mm}$ for Iraqi and Chinese seed extract respectively) and $P$. aerugerosa $(12 \mathrm{~mm}$ and $10 \mathrm{~mm}$ for Iraqi and Chinese seed extract respectively) when compared to results from current study [12]. The biological property of a plant can be attributed due to nutrients content which is in turn differ from one geographical area to another as revealed by studies above mentioned studies.

\section{Conclusion}

As revealed from the data presented in this work, it can be concluded that, pumpkin wastes can be used in some other possible ways rather than being discarded. All the three pumpkin wastes used in this study show potential antioxidant capacity using various antioxidant assays. With regard to antimicrobial activity, little activity was reported against the tested bacterial species. Perhaps more resistant species were used in the study. At the end, it can be said that, the pumpkin seed, back and brain are of bioactive importance therefore can be used for food and pharmaceutical industries to explore their potentials.

\section{References}

1. Azizah AH, Wee KC, Azizah O, Azizah M (2009) Effect of boiling and stir frying on total phenolics, carotenoids and radical scavenging activity of pumpkin (Cucurbita moschato). Int Food Res J 16: 45-51.

2. Perez GRM (2016) Review of Cucurbita pepo (Pumpkin) its phytochemistry and pharmacology. Medchem 6: 12-21.

3. Karanja JK, Mugendi BJ, Khamis FM, Muchugi AN (2013) Nutritional composition of the pumpkin (Cucurbita spp.) seed cultivated from selected regions in Kenya. J Hortic Lett 3: 17-22.

4. Silver B (2016) Pumpkins. J Agri Food Info 17: 206-211.

5. Saavedra MJ, Aires A, Dias C, Almeida JA, de Vasconcelos MC, et al. (2015) Evaluation of the potential of squash pumpkin by-products (seeds and shell) as sources of antioxidant and bioactive compounds. J Food Sci Technol 52: 1008-1015.

6. Aruah CB, Uguru MI, Oyiga BC (2011) Nutritional evaluation of some Nigerian pumpkin Cocubita spp. Fruit Veg Cereal Sci Biotech 5: 64-71.

7. Velioglu YS, Mazza G, Gao L, Oomah BD (1998) Antioxidant activity and total phenolics in selected fruits, vegetables and grain products. J Agric Food Chem 46: 4113-4117.

8. Yen GC, Chen HY (1995) Antioxidant activity of various tea extracts in relation to their antimutagenicity. J Agric Food Chem 43: 27-32.

9. Prieto P, Pineda M, Aguilar M (1999) Spectrophotometric quantitation of antioxidant capacity through the formation of a phosphomolybdenum complex: Specific application to the determination of vitamin E. Anal Biochem 269: 337-41.

10. Klein SM, Cohen G, Cederbaum AI (1991) Production of formaldehyde during metabolism of dimethyl sulphoxide by hydroxyl radical generating system. Biochem 20: 6006-6012.

11. Blois MS (1958) Antioxidant determinations by the use of a stable free radical. Nature 29: 1199-1200.

12. Jagessar RC, Mars A, Gones G (2008) Selective anti-microbial properties of leaf extract against various micro-organism using disc diffusion and agar well diffusion method. J Nature Sci 6: 24-38.

13. Ames BN, Shigena MK, Hagen TM (1993) Oxidants, antioxidants and the degenerative diseases of aging. Proc Natl Sci USA 90: 7915-7922. 
Citation: Abdullahi II and Santhose I (2018) Comparative Analysis on Antioxidant and Antibacterial Activity of Pumpkin Wastes. J Antimicrob Agents 4: 180. doi:10.4172/2472-1212.1000180

Page 6 of 6

14. Javaherashti M, Ghasemnezhad M, Lahiji HS, Shiri MA (2012) Comparison of nutritional value and antioxidant compounds of some winter pumpkin (Cucurbita spp.) species fruits in Iran. Adv Environ Biol 6: 2611-2616.

15. Sakka D, Karantonis HC (2015) In vitro health beneficial activities of pumpkin seeds from Cucurbita moschata cultivated in Lemnos. Int J Food Studies 4: 221-237.

16. Gupta D, Kaur P (2016) Physiochemical evaluation and in vitro antioxidant activity of few wonder seeds. Int J Pharm Pharm Sci 8: 98-104.
17. Verma AR, Vijayakumar M, Rao CV, Mathela CS (2010) In vitro and in vivo antioxidant properties and DNA damage protective activity of green fruit of Ficus glomerata. Food Chem Toxicol 48: 704-709.

18. Dubey A, Mishra N, Singh N (2010) Antimicrobial activity of some selected vegetables. Int J Appl Biol Pharm 1: 994-999.

19. Chonoko UG, Rufai AB (2011) Phytochemical screening and antibacterial activity of Cucurbita pepo (pumpkin) against Staphylococcus aureus and Salmonella typhi. Bayero J Pure Appl Sci 4: 145-147. 